\title{
Effectiveness of Chronic Disease Management Program in Improving the Quality of Life under National Health Insurance
}

\author{
Misnaniarti Misnaniarti, Iwan Stia Budi, Asmaripa Ainy
}

\begin{abstract}
Purpose: The Chronic Disease Management Program (Prolanis) implemented at Puskesmas with the concept of cost effective and efficient health services in the National Health Insurance (JKN). Prolanis intended for participants who suffer from chronic diseases to achieve optimal Quality of Life (QoL). Therefore, aims this study to assess the effectiveness of Prolanis services in improving the quality of life of JKN participants in Banyuasin District.

Methodology: This study using a cross sectional design, data was taken in 2018. Population is people who suffer from chronic diseases (type 2 Diabetes Mellitus and Hypertension). Sample was pre-elderly dan elderly as Puskesmas visitors in Banyuasin District was chosen by proportional random sampling ( $n=250$ people). Data collection used the WHOQOL-BREF questionnaire through direct interviews with respondents. Data analysis using bivariate and multivariate analysis.

Main Findings: The respondents were most underage of 60 years (participants of $63.4 \%$ and non-participants of $74.1 \%$ ). Most of respondents had moderate exercise habits (participants of 59.9\% and non-participants of 51.9\%), among others: walking, jogging, cycling, or other sports. Body Mass Index in normal category (participants of $62.0 \%$ and non-participants of 64.8\%). It's known that Prolanis participants (61.3\%) and non-participants $(53.7 \%)$ have majority perception of a good QoL. Respondents who are willing to become Prolanis participants are around 142 people (56.8\%).

Application: The Puskesmas can improve socialization and motivation for participants to use Prolanis services, and to increase the frequency of gymnastic club activities continuously so that there are many time choices.

Novelty: Participants who used Prolanis services more often, will have a higher QoL score. Respondents who visited Prolanis services 3-4 times had a tendency to be 1.3 times more likely to have a good perception of QoL (RR:1.33; C195\%:0.71-2.49).
\end{abstract}

Keywords: Elderly, Prolanis, Puskesmas, Quality of Life, WHOQOL-BREF.

\section{INTRODUCTION}

Health development in Indonesia for the 2015 to 2019

Revised Manuscript Received on September 22, 2019

Misnaniarti Misnaniarti, Department of Health Policy and Administration, Faculty of Public Health, Sriwijaya University. Palembang-Prabumulih Street KM.32, Indralaya, South Sumatera, Indonesia. isnaniarti@fkm.unsri.ac.id

Iwan Stia Budi, Department of Health Policy and Administration, Faculty of Public Health, Sriwijaya University. Palembang-Prabumulih Street KM.32, Indralaya, South Sumatera, Indonesia

Asmaripa Ainy, Department of Health Policy and Administration, Faculty of Public Health, Sriwijaya University. Palembang-Prabumulih Street KM.32, Indralaya, South Sumatera, Indonesia period has 3 main pillars, namely: 1)Healthy paradigm, with strategies for mainstreaming health in development, strengthening preventive promotion and community empowerment; 2)Strengthening health services, with strategies to improve access to health services, optimize referral systems and improve the quality of health services, using a continuum of care approach and the health risk-based interventions; 3)National health insurance, carried out with a strategy to expand targets and benefits as well as quality control and cost control. ${ }^{(1)}$

Since 2014, the National Health Insurance (JKN) was implemented in Indonesia as mandated by the National Social Security System Law (SJSN Law) in order to provide more comprehensive and integrated social protection for the people of Indonesia. In Article 22 paragraph 1 of the SJSN Law, it is stated that health insurance benefits are individual services in the form of health services which include promotive, preventive, curative, and rehabilitative services, including medicines and medical materials that are needed. ${ }^{(2)}$

The Health Social Security Administrator (Badan Penyelenggaran Jaminan Sosial, abbreviated as the Health $B P J S)$ is the implementing agency formed to organize National Health Insurance programs for all Indonesian people. One of the programs implemented by the health BPJS is The Chronic Disease Management Program (Prolanis). Prolanis is an integrated health service and proactive approach that involves Participants, Health Facilities and the Health BPJS in the context of health care for $J K N$ participants who suffer from chronic illnesses to achieve optimal quality of life (QoL) using an effective and efficient health service cost scheme. ${ }^{(3)}$

Quality of life is defined as individuals' perceptions of their position in life in the context of the culture and value systems in which they live and in relation to their goals, expectations, standards and concerns. This definition reflects the view that quality of life refers to a subjective evaluation which is embedded in a cultural, social and environmental contex. ${ }^{(4)}$

Prolanis participants' targets are all JKN participants who suffer from chronic diseases (Type 2 Diabetes Mellitus and Hypertension). Activities in Prolanis include the medical consultation activities (educational), home visits, Short Message Service (SMS) reminder, club activities and monitoring health status.

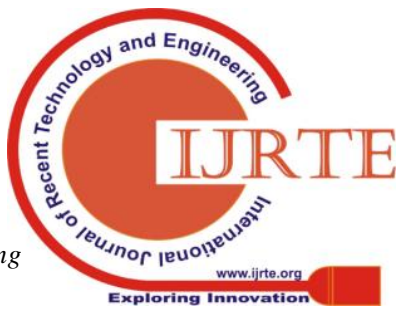


Therefore, for pre-elderly and elderly people, Prolanis is very useful for achieving high quality of life. ${ }^{(3)}$

The problem that needs to be considered is that there are still many $J K N$ participant in pre-elderly/elderly group who do not use this program. Therefore, the purpose of this study was to assess the effectiveness of the Chronic Disease Management Program in improving the Quality of Life for pre-elderly and elderly people.

\section{LITERATURE REVIEW}

\section{A. Chronic Disease Management Program (Prolanis)}

The benefits of $J K N$ include promotive, preventive, curative and rehabilitative services including the service of medicines and consumables according to medical needs. The benefits of promotive and preventive services include services: 1)Individual health counseling, 2)Basic immunization, 3)Family Planning, 4)Health screening. This service given selectively which aims to detect risk of disease and prevent the continued impact of the risk of diseases. ${ }^{(5)}$

Preventive and curative services carried out under $J K N$ are the Chronic Disease Management Program (Prolanis) which is an integrated health service and proactive approach that involves Participants, Health Facilities and Health BPJS in the context of health care for BPJS Health participants who suffer from chronic diseases to achieve optimal quality of life with the cost of effective and efficient health services. $^{(3)}$

Prolanis is a continuation of health screening. If results the health history screening of $J K N$ participants' indicate that they have risk factors for type 2 diabetes mellitus or hypertension, they can participate in Prolanis. The aim of Prolanis is to encourage participants with chronic diseases to achieve optimal quality of life with an indicator that $75 \%$ of registered participants who visit First Level Health Facilities (Clinics/ Puskesmas) have "good" results on specific tests for Type $2 \mathrm{DM}$ and Hypertension. It is expected to be able to prevent complications of disease. ${ }^{(3)}$

Activities in Prolanis include services such as: 1)Medical consultation, 2)Education, 3)Home Visit, 4)Reminder, 5)Club activities, and 6)Monitoring health status. The following for a more detailed explanation of this: ${ }^{(3)}$

- Medical concultation; through this activity, Prolanis participants can make an agreed consultation schedule together with health facilities.

- Education; Educational Club (Prolanis Club) is an activity to improve health knowledge in an effort to restore disease and prevent the re-emergence of diseases and improve health status for Prolanis participants. Health facilities are expected to form a minimum of 1 group of participants (clubs), grouping based on participants' health conditions and educational needs

- Reminder through SMS Gateway; is an activity to motivate participants to make regular visits to health facilities through consultation schedule reminders. Health facilities do recapitulation of each cellphone number of Prolanis participants or families participants, then health facilities will enter cellphone number data into the SMS Gateway application. In addition, data recapitulation of participants' visits to health facilities was carried out. Health facilities will analyze the data based on number of participants who received a reminder with number of visits

- Home visit; is a service activity of Prolanis participants' home visits to provide information (health education) for participant and family. The target is Prolanis participants with criteria: a)Participants have just registered, b)Participants do not attend for therapy at General Practitioners/clinical/Puskesmas for 3 consecutive months, c)Participants with substandard GDP/GDPP for 3 consecutive months, d)Participants with uncontrolled Blood Pressure for 3 consecutive months, e)Participants after hospitalization

Prolanis using concept of preventive and promotive services, to implement effective and efficient services. Based on other study, ${ }^{(6)}$ recommend to encouraging people to take preventive measures and use preventive care services. It is great importance, to promote population health and better control the escalating medical expenditures resulting from the rapid growing aging population.

\section{B. Quality of Life (QoL)}

Quality of life is defined as individuals' perceptions of their position in life in the context of the culture and value systems in which they live and in relation to their goals, expectations, standards and concerns. This definition reflects the view that quality of life refers to a subjective evaluation which is embedded in a cultural, social and environmental context. ${ }^{(4)}$ It is a broad ranging concept affected in a complex way by the person's physical health, psychological state, level of independence, social relationships, personal beliefs and their relationship to salient features of their environment. ${ }^{(7)}$

\section{Measuring Quality of Life}

The World Health Organization develops an instrument to measure quality of life namely WHO Quality of Life-BREF (WHOQOL-BREF), contains a total of 26 questions. The WHOQOLBREF has been developed to provide a short form quality of life assessment, using data from the WHOQOL-100. The WHOQOL-100 allows detailed assessment of each individual facet relating to quality of life. In certain instances however, the WHOQOL-100 may be too lengthy for practical use. ${ }^{(4)}$

The WHOQOL-BREF consisting of four domains: physical health, psychological, social relationship, and environmental (see Table 1). To provide a broad and comprehensive assessment, one item from each of the 24 facets contained in the WHOQOL-100 has been included. In addition, including two item are: the overall quality of life and general health facet.

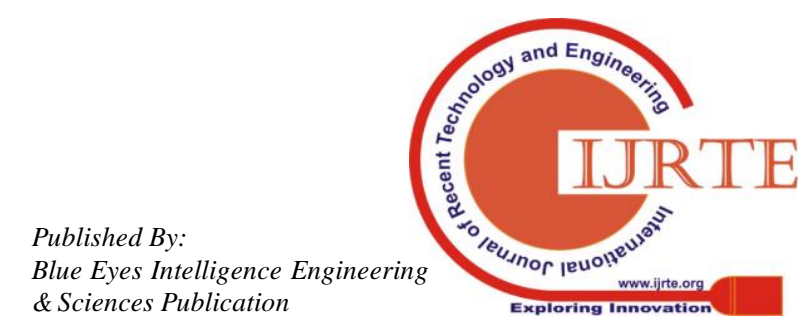


Table 1. Items of questions in WHOQOL-BREF domain

\begin{tabular}{ccc}
\hline WHOQOL-BREF & $\begin{array}{c}\text { Items } \\
\text { Question }\end{array}$ & Questions Number \\
\hline $\begin{array}{c}\text { Physical health } \\
\text { domain }\end{array}$ & 7 & $3,4,10,15,16,17$, dan \\
$\begin{array}{c}\text { Psychological } \\
\text { domain }\end{array}$ & 6 & $5,6,7,11,19$, dan 26 \\
$\begin{array}{c}\text { Social relationships } \\
\text { domain }\end{array}$ & 3 & 20,21, dan 22 \\
$\begin{array}{c}\text { Environment } \\
\text { domain }\end{array}$ & 8 & $8,9,12,13,14,23,24,25$
\end{tabular}

Sources: WHO (1996)

The WHOQOL-BREF is a valid and reliable instrument for measuring quality of life for elderly people, according to studies conducted in several regions. ${ }^{(8-12)}$ Study in Jakarta City, using discriminant validity, construct validity, and internal consistency showed good results from each domain of WHOQOL-BREF. The score distribution is almost symmetrical and there is no floor or ceiling effect. But a little improvement is still needed. ${ }^{(10)}$

\section{Methodology/Materials}

\section{A. Design and Sample}

This study using cross sectional design, is a research method that studies the prevalence, distribution and correlation of exposure factors (independent variables) and effect factors (dependent variable). This method measures the variables only once simultaneously at one time. ${ }^{(13,14)}$

The population in this study were pre-elderly and elderly people in Banyuasin District of South Sumatra Province. Samples aged 40 years and above who suffer from chronic diseases (Type 2 Diabetes Mellitus and Hypertension) who visit the Puskesmas that implements Prolanis services in Banyuasin District of South Sumatra Province.

There are 10 Puskesmas in Banyuasin District that implement Prolanis services in 2018. Puskesmas samples grouped into 2 groups, are: a) safe category, and b) not-safe category. Puskesmas randomized so that 4 region Puskesmas were selected as sample areas, consisting of: the Kenten-Laut Puskesmas, the Sukajadi Puskesmas, the Sembawa Puskesmas, the Pangkalan-Balai Puskesmas.

Sample size calculated based on formula for two population proportions ${ }^{(15)}$ with alpha $5 \%(\mathrm{Z} 1-\alpha=1.96)$. Minimum sample of 250 people was taken using proportional random sampling method. Inclusion criteria are: visitors aged $\geq 40$ years, suffering from chronic illness ((Type 2 Diabetes Mellitus and Hypertension). Disease criteria based on doctor's diagnosis.

\section{B. Data}

This research taken individual questionnaires using the WHOQOL-BREF instrument, which consists of 26 question items. $^{(4,12,16)}$ This instrument uses four dimensions, are: physical health, psychological, social relationship, and environmental. All questions based on a Likert scale (point 1 to 5). For questions number 1 and 2 about overall quality of life and health in general, while for other questions are questions from each domain. ${ }^{(16)}$

This instrument consists of positive questions, except for 3 questions No. 3, 4 and 26 which are negative. In this study the score of each domain (raw score) is transformed on a scale of 0 to $100 .^{(4)}$ Dependent variable is quality of life, measured from the overall quality of life which grouped into two categories: good (for the respondent's answer; good, and very good), not-good (for the respondent's answer; very bad, bad, and Neither bad nor good).

Independent variables consist of participation in Prolanis, frequency of visits to Prolanis (in the last month), diagnosis, exercise habits, Body Mass Index (BMI), domains in WHOQOL-BREF (physical health, psychological welfare, social relationships, environmental relationships). Each question in domain are given a value of 1 to 5 , and a higher value is a better quality of life. The BMI variables grouped by references ${ }^{(17,18)}$ consist of: normal $(18.5-25.0)$, less than normal $(<18.5)$, more than normal $(>25.0)$.

\section{Statistical Analysis}

All the data were analyzed using univariate analysis to see frequency distribution of each variable. Measurements done on each domain, using the formula:

Physical health domain $=(6-\mathrm{Q} 3)+(6-\mathrm{Q} 4)+\mathrm{Q} 10+\mathrm{Q} 15+$ $\mathrm{Q} 16+\mathrm{Q} 17+\mathrm{Q} 18$

Psychological welfare domain $=\mathrm{Q} 5+\mathrm{Q} 6+\mathrm{Q} 7+\mathrm{Q} 11+$ $\mathrm{Q} 19+(6-\mathrm{Q} 26)$

Social relationships domain $=\mathrm{Q} 20+\mathrm{Q} 21+\mathrm{Q} 22$

Environmental relationships domain $=\mathrm{Q} 8+\mathrm{Q} 9+\mathrm{Q} 12+$ $\mathrm{Q} 13+\mathrm{Q} 14+\mathrm{Q} 23+\mathrm{Q} 24+\mathrm{Q} 25$

Continuous data in domain variables grouped into two categories: good (if $\geq 75 \%$ answers to each domain), enough (if less than $75 \%$ answers to each domain). Furthermore, bivariat analysis done using chi-square test, and multivariate analysis using multiple logistic regression (full model).

\section{RESUltS AND FINDINGS}

\section{A. Descriptive Statistic}

Based on this study known there are 142 Prolanis participants, and 108 non-participants as respondents. Characteristics of respondents can be seen in Table 2, known that participants $(63.4 \%)$ and non-participants $(74.1 \%)$ were most underage of 60 years. It shows there are awareness of respondents who are not elderly to become Prolanis participants. In addition, maybe because most of respondents as Prolanis participants (71.1\%) suffered from hypertension before becoming elderly. 
Table 2. Proportion of respondents based on their characteristics

\begin{tabular}{|c|c|c|c|c|c|}
\hline \multirow[t]{2}{*}{ Variables } & \multirow[t]{2}{*}{ Category } & \multicolumn{2}{|c|}{$\begin{array}{c}\text { Prolanis } \\
\text { Participant } \\
\text { s }\end{array}$} & \multicolumn{2}{|c|}{$\begin{array}{c}\text { Non-Prolan } \\
\text { is } \\
\text { Participant } \\
\text { s }\end{array}$} \\
\hline & & n & $\%$ & $\mathbf{n}$ & $\%$ \\
\hline Age & $\begin{array}{c}40-59 \text { years } \\
\text { More than } 60 \\
\text { years }\end{array}$ & $\begin{array}{l}90 \\
52\end{array}$ & $\begin{array}{l}63.4 \\
36.6\end{array}$ & $\begin{array}{l}80 \\
28\end{array}$ & $\begin{array}{l}74.1 \\
25.9\end{array}$ \\
\hline Sex & $\begin{array}{c}\text { Female } \\
\text { Male }\end{array}$ & $\begin{array}{l}91 \\
51\end{array}$ & $\begin{array}{l}64.1 \\
35.9\end{array}$ & $\begin{array}{l}52 \\
56\end{array}$ & $\begin{array}{l}48.1 \\
51.9\end{array}$ \\
\hline
\end{tabular}

$\begin{array}{lccccc} & \text { level } & & & & \\ \text { Education } & \text { Secondary School } & 95 & 66.9 & 23 & 58.3 \\ & \text { level } & 25 & 17.6 & 22 & 20.4 \\ & \text { High School and } & 22 & 15.5 & 23 & 21.3\end{array}$

Above

Civil

servants/Retireme $\begin{array}{lllll}\text { nt } & 14 & 9.9 & 10 & 9.3\end{array}$

$\begin{array}{llllll}\text { Occupation } & \text { Entrepreneur } & 41 & 28.9 & 29 & 26.9\end{array}$

$\begin{array}{lllll}\text { Housewife/Labore } & 87 & 61.3 & 69 & 63.9\end{array}$ $\mathrm{r} /$ None

Marital

Married status

Widow/Widower

$\begin{array}{llll}112 & 78.9 & 89 & 82.4\end{array}$

$\begin{array}{llll}30 & 21.1 & 19 & 17.6\end{array}$

Hypertension

Diabetes Mellitus

$\begin{array}{lllll}(\mathrm{DM}) & 101 & 71.1 & 84 & 77.8\end{array}$

$\begin{array}{llllll}\text { Diagnosis } & \text { Hypertension and } & 28 & 19.7 & 9 & 8.3 \\ & 13 & 9.2 & 15 & 13.9\end{array}$ $\begin{array}{lllll}\text { DM } & 13 & 9.2 & 15 & 13.9\end{array}$

$\begin{array}{clllll} & \text { Yes } & & & & \\ \text { Exercise } & \text { No } & 59 & 59.9 & 56 & 51.9 \\ \text { habits } & & 57 & 40.1 & 52 & 48.1\end{array}$

Normal (18.5 25)

Body Mass

$\begin{array}{lllll}\text { Less than normal } & 88 & 62.0 & 70 & 64.8\end{array}$ $\begin{array}{lllll}(<18.5) & 36 & 25.4 & 29 & 26.9\end{array}$ $\begin{array}{lllll}\text { More than normal } & 18 & 12.7 & 9 & 8.3\end{array}$ $(>25.0)$

Total

$\begin{array}{llll}142 & 100 & 108 & 100\end{array}$

Majority of Prolanis participants were women (64.1\%), while most non-participants were men (51.9\%). Majority of education are from elementary school (participants of $66.9 \%$ and non-participants of 58.3\%). Majority of respondents were housewives/laborers /non-working (61.3\% and 63.9). This may be because women or respondents who do not work have more time to visit Puskesmas that have limited service hours.

Most of respondents had moderate exercise habits (participants 59.9\% and non-participants 51.9\%), among others: walking, jogging, cycling, or other sports. These sports are activities carried out by respondents over the past 1 month.

Still based on Table 2, it's known that BMI on participants (62.0\%) and non-participants (64.8\%) have a normal BMI category. However, awareness is needed, because many respondents who have BMIs below normal, as well as Prolanis participants who tend to have a higher proportion of BMI more than normal $(12.7 \%)$. Based on further analysis, it is known that respondents who have more than normal BMI occur mostly in the age group of respondents under 60 years $(77.8 \%)$.

Table 3. Proportion of respondents based on perceptions of their QoL

\begin{tabular}{|c|c|c|c|c|c|}
\hline \multirow[t]{2}{*}{ Variables } & \multirow[t]{2}{*}{ Category } & \multicolumn{2}{|c|}{$\begin{array}{c}\text { Prolanis } \\
\text { Participant } \\
\text { S }\end{array}$} & \multicolumn{2}{|c|}{$\begin{array}{c}\text { Non-Prolan } \\
\text { is } \\
\text { Participant } \\
\text { s }\end{array}$} \\
\hline & & $\mathbf{n}$ & $\%$ & n & $\%$ \\
\hline \multirow{6}{*}{$\begin{array}{c}\text { Overall } \\
\text { Quality of Life } \\
\text { (Q1) }\end{array}$} & Very bad & & & & \\
\hline & $\mathrm{Bad}$ & 0 & 0 & 0 & 0 \\
\hline & Neither bad nor & 1 & 0.7 & 1 & 0.9 \\
\hline & good & 50 & 35.2 & 42 & 38.9 \\
\hline & Good & 87 & 61.3 & 58 & 53.7 \\
\hline & Very good & 4 & 2.8 & 7 & 6.5 \\
\hline \multirow{2}{*}{$\begin{array}{l}\text { Q1 (into } 2 \\
\text { categories) }\end{array}$} & Good & 91 & 64.1 & 65 & 60.2 \\
\hline & & 51 & 35.9 & 43 & 39.8 \\
\hline \multirow{6}{*}{$\begin{array}{l}\text { Overall of } \\
\text { health } \\
\text { satisfaction } \\
\text { (Q2) }\end{array}$} & Very dissatisfied & 0 & 0 & 0 & 0 \\
\hline & Dissatisfied & 29 & 20.4 & 16 & 14.8 \\
\hline & $\begin{array}{c}\text { Neither satisfied } \\
\text { nor dissatisfied }\end{array}$ & 57 & 40.1 & 41 & 38.0 \\
\hline & Satisfied & 50 & 35.2 & 34 & 31.5 \\
\hline & Very satisfied & 6 & 4.2 & 17 & 15.7 \\
\hline & Total & 142 & 100 & 108 & 100 \\
\hline
\end{tabular}

Based on Table 3, it's known that Prolanis participants $(61.3 \%)$ and non-participants $(53.7 \%)$ have majority perception of a good QoL. However, on perception of their health, majority of Prolanis participants rated their health as normal (40.1\%) and non-participant (38.1\%), although the difference in proportion was not so far with respondents who judged satisfaction with their health condition.

\section{B. Bivariat Analysis}

The analysis done to determine whether there was a difference in the proportion of each group of variables, and correlations with QoL of respondents in participants and non-participants can be seen in Table 4: 
Table 4. Correlation between Participation in Prolanis with perception QoL

\begin{tabular}{cccccccc}
\hline & \multicolumn{4}{c}{ Overall QoL } & p & \\
Variables & Good & $\begin{array}{c}\text { Not-goo } \\
\text { d }\end{array}$ & $\begin{array}{c}\text { valu } \\
\text { RR } \\
\text { (CI95\%) }\end{array}$ \\
& n & $\%$ & $\mathbf{n}$ & $\%$ & e & \\
\hline Participation in & & & & & & \\
Prolanis: & & 64. & & 35. & & 1.18 \\
Member & 91 & 1 & 51 & 9 & 0.61 & $(0.70-1.98$ \\
Non-member & 65 & 60. & 43 & 39. & 8 & ) \\
& & 2 & & 8 & & 1
\end{tabular}

Frequency of visits to

Prolanis (in the last

$$
\begin{aligned}
& \text { month): } \\
& \text { 3-4 times } \\
& \text { 1-2 times } \\
& \text { None }
\end{aligned}
$$

$\begin{array}{cccccc} & 53 . & & 46 . & 1.33 \\ & 2 & & 8 & & (0.71-2.49 \\ 33 & 72 . & 29 & 27 . & 0.04 & ) \\ 58 & 5 & 22 & 5 & 9 & 0.57 \\ 65 & 50 . & 43 & 39 . & & (0.31-1.07 \\ & 60 . & & 8 & ) \\ & 2 & & & & 1\end{array}$

$$
\text { Total } \quad 156 \begin{array}{ccc}
62 . & 94 & 37 . \\
& 4 & 6
\end{array}
$$

Visitors of Puskesmas (as $J K N$ participants) who are willing to become Prolanis participants are around 142 people $(56.8 \%)$. Respondents who visited Prolanis services 3-4 times had a tendency to be 1.3 times more likely to have a good perception of QoL (RR:1.33; CI95\%:0.71-2.49). This shown that the service in Prolanis is statistically correlation with QoL of the respondents.

Similiarity with study in Taiwan shown that the National Health Insurance (NHI) system in Taiwan provides free annual preventive care services and other disease-specific preventive care services under low copayments to people aged 65 and older, yet their utilization rates remain low ever since implementation. Under Taiwan's NHI, most preventive care services are provided on a periodical basis at low copayments to people aged 65 and older, but the utilization rates remain low. ${ }^{(6)}$

Study in China found those with health insurance use more preventive care but do not report significantly better health outcomes. It's shown that $21 \%$ of them used preventive health care (19). In order to improve the health of the elderly and reduce the escalation of medical expen-ditures due to aging, implementing preventive care in the health insurance is a very effective strategy. ${ }^{(20)}$

\section{Regression result}

Next, multiple rogistic regression analysis done on variables correlation with QoL (see Tabel 5). Analysis using full model method, known that variable of participation in Prolanis has correlation with perception QoL. Prolanis participants tend to be 1.6 times more likely to have a good perception of QoL than non-participants (OR:1.59; CI95\%:0.81-3.13).

Similiarity with frequency of visit, participants who visit 3-4 times per month to Prolanis services have tend to be 1.6 times more likely to have a good perception of QoL than respondents who do not visit (OR:1.59; CI95\%:0.74-3.39).

Based other study known, that exercise habits correaltion with quality of life. ${ }^{(21)}$

On four QoL domains, known that respondents who have a good physical health domain tend to be 2.2 times more likely to have a good perception of QoL than respondents who have a enough physical health domain (OR:2.18; CI95\%:1.04-4.57).

Table 5. Multiple rogistic regression analysis results on variables correlation with QoL

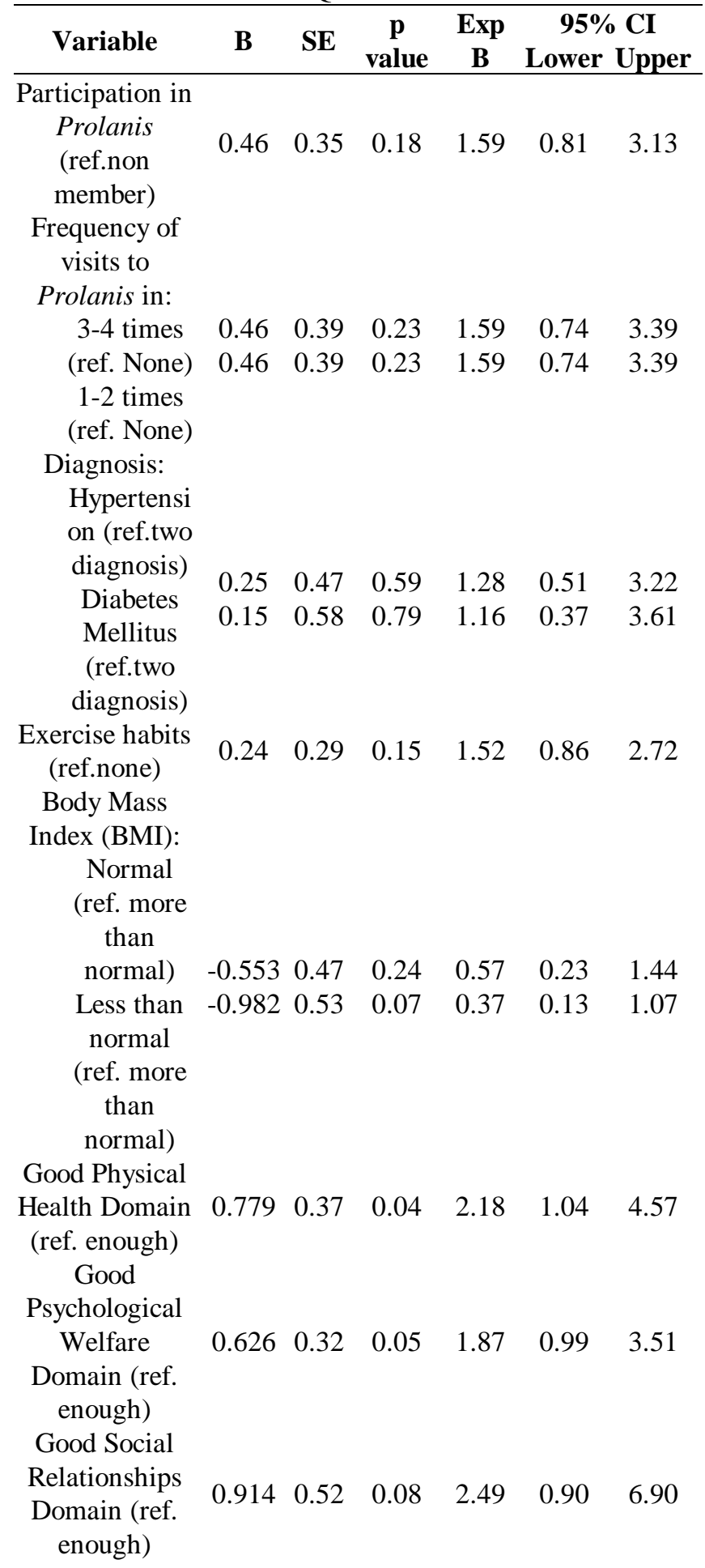


Good

Environmental

\begin{tabular}{ccccccc}
$\begin{array}{c}\text { Relationships } \\
\text { Domain (ref. } \\
\text { enough) }\end{array}$ & 0.142 & 0.48 & 0.76 & 1.15 & 0.45 & 2.94 \\
Constant & -5.937 & 1.45 & 0.0001 & 0.003 & & \\
\hline
\end{tabular}

Based on this analysis known the variable which has the strongest correlation with QoL is social relationships domain. Respondents who have a good social relationship domain tend to be 2.5 times more likely to have a good perception of QoL than respondents who have a enough social relationships domain (OR:2.49; CI95\%:0.90-6.90). Nagelkerke $\mathrm{R}=0.168$ so that the independent variables are able to explain the dependent variable by $16.8 \%$.

Study in Swiss shown that patients with diabetes perceive their physical function-ing as lower compared to the population-based norm, the QoL measure tells us which life domains are particularlyaffected by diabetes, namely the freedom to eat and drinkas wished, and sex life. The factors independently associatedwith health status and QoL can help healthcare providers toidentify patients at higher risk of lower physical functioning,mental well-being and QoL. ${ }^{(22)}$

\section{Conclusion}

\section{A. Conclusion}

Based on this study concluded that respondents who used Prolanis services more often, will have a higher QoL score. The variable of participation in Prolanis has correlation with perception QoL. Prolanis participants tend to be 1.6 times more likely to have a good perception of QoL than non-participants (OR:1.59; CI95\%:0.81-3.13). Participants who visit 3-4 times per month to Prolanis services have tend to be 1.6 times more likely to have a good perception of QoL than respondents who do not visit (OR:1.59; CI95\%:0.74-3.39).

\section{B. Recommendation}

Recommendations for Puskesmas, can increase the motivation of participants to come to Prolanis activities, through increasing of services such as: implement of gymnastic club activities regularly, simplify the drug retrieval system, socialization to the community, so that they know the existence and benefits of Prolanis activities.

Suggestions for participants to increase their attention and awareness of health so that chronic diseases are controlled and can improve their quality of life. Increase their participation in activities organized by Prolanis through a scheduled visit and continuously.

\section{ACKNOWLEDGEMENTS}

This research work is supported by the Competitive Research Grant year 2018 (No. 042.01.2.400953/2018), supported by Sriwijaya University.

\section{REFERENCES}

[1] Ministry of Health. Rencana Strategis Kementerian Kesehatan Tahun 2015-2019. Jakarta: Kementerian Kesehatan Republik Indonesia; 2015.
[2] Undang-Undang Nomor 40 tahun 2004 about Sistem Jaminan Sosial Nasional, (2004).

[3] BPJS. Panduan Praktis PROLANIS (Program Pengelolaan Penyakit Kronis). Jakarta: Badan Penyelenggaran Jaminan Sosial (BPJS) Kesehatan; 2014.

[4] WHO. WHOQOL-BREF; Introduction, administration, scoring and generic version of the assessment. Geneva: World Health Organization, 1996.

[5] Ministry of Health. Buku Pegangan Sosialisasi Jaminan Kesehatan Nasional (JKN) dan Sistem Jaminan Sosial Nasional. Jakarta: Kementerian Kesehatan RI; 2013.

[6] Peng Y-I, Lin T-F. Social capital and preventive care use among the elderly under Taiwan's National Health Insurance. Archives of Gerontology and Geriatrics. 2018;75:28-36.

[7] WHO. Programme on Mental Health, WHOQOL Measuring Quality of Life. Geneva: World Health Organization; 1997.

[8] Skevington SM, Lotfy M, O'Connell KA. The World Health Organization's WHOQOL-BEF quality of life assessment: Psychometric properties and results of the international field trial. A Report from the WHOQOL Group. Quality of Life Research. 2004;13:299-310.

[9] Bonomi AE, Patrick DL, Bushnell DM, Martin M. Validation of the United States' version of the World Health Organization quality of life (WHOQOL) instrument. Journal of clinical epidemiology. 2000;53(1):1-12.

[10] Salim OC, Sudharma NI, Kusumaratna RK, Hidayat A. Validitas dan Reliabilitas World Health Organization Quality of Life-BREF untuk mengukur Kualitas hidup lanjut usia. Universa Medicina. 2007;26(1):27-38.

[11] Berlim MT, Pavanello DP, Caldieraro MAK, Fleck MPA. Reliability and Validity of the WHOQOL BREF in a sample of Brazilian Outpatients with Major Depression. Quality of Life Research. 2005;14(2):561-4.

[12] WHO. Development of the World Health Organization WHOQOL-BREF Quality of Life Assessment. Psychological Medicine. 1998;28:551-8.

[13] Murti B. Prinsip dan Metode Riset Epidemiologi (edisi kedua). Yogyakarta: Gadjah Mada University Press; 2003.

[14] Sastroasmoro S, Ismael S. Dasar-Dasar Metodologi Penelitian Klinis. Jakarta: Bina Rupa Aksara; 1995.

[15] 1Lemeshow S, Hosmer DW, Klar J, Lwanga SK. Besar Sampel dalam Penelitian Kesehatan (edisi Bahasa Indonesia). Yogyakarta: Gadjah Mada University Press; 1997.

[16] WHO. The World Health Organization Quality of Life (WHOQOL)-BREF. Geneva: World Health Organization, 2004.

[17] WHO. Nutrition Landscape Information System (NLIS) Country Profile Indicators; Interpretation Guide. Geneva: World Health Organization; 2010.

[18] Ministry of Health. Pedoman Gizi Seimbang, pedoman teknis bagi petugas dalam memberikan penyuluhan gizi seimbang. Jakarta: Kementerian Kesehatan RI; 2014.

[19] He H, Nolen PJ. The effect of Health Insurance reform: Evidence from China. China Economic Review. 2019;53(2019):168-79.

[20] Chen C-S, Peng Y-I, Lee P-C, Liu T-C. The effectiveness of preventive care at reducing curative care risk for the Taiwanese elderly under National Health Insurance. Health Policy. 2015;119(6):787-93.

[21] Lara AG, Hidajah AC. Hubungan pendidikan, kebiasaan olahraga dan pola makan dengan kualitas hidup lansia di Puskesmas Wonokromo Surabaya. Jurnal Promkes. 2016;4(1):59-69.

[22] Arditi C, Zanchi A, Peytremann-Bridevaux I. Health status and quality of life in patients with diabetes in Switzerland. Primary Care Diabetes. 2018

\section{AUTHORS PROFILE}

My name is Misnaniarti Misnaniarti, is associated with Department of Health Policy and Administration, Faculty of Public Health, Sriwijaya University. Palembang-Prabumulih Street KM.32, Indralaya, South Sumatera, Indonesia. My area of interest is public health.

I am Iwan Stia Budi, I am curremtly associated wth Department of Health Policy and Administration, Faculty of Public Health, Sriwijaya University. Palembang-Prabumulih Street KM.32, Indralaya, South Sumatera, Indonesia . My area of interest is public health. 